\title{
EAST VARDAR OPHIOLITES REVISITED: A BRIEF SYNTHESIS OF GEOLOGY AND GEOCHEMICAL DATA
}

\author{
Blažo Boev ${ }^{*}$, Vladica Cvetković², Dejan Prelević², Kristina Šarić Ivan Boev $^{1}$ \\ ${ }^{1}$ Goce Delčev University, Štip, Republic of Macedonia \\ ${ }^{2}$ Faculty of Mining and Geology, University of Belgrade, Belgrade, Serbia \\ e-mail: blazo.boev@ugd.edu.mk
}

\begin{abstract}
The study reports and synthesizes the available geological and geochemical data on the East Vardar ophiolites comprising most known occurrences from the South Apuseni Mountains in Romania to the tip of the Chalkidiki Peninsula in Greece. The summarized geological data suggest that the East Vardar ophiolites are mostly composed of the magmatic sequences, whereas the mantle rocks are very subordinate. The members of the magmatic sequences are characterized by the presence of abundant acid and intermediate volcanic and intrusive rocks. The age of these ophiolites is paleontologically and radiometrically constrained and these data suggest that the East Vardar ophiolite formed as a short-lived oceanic realm that was emplaced before the uppermost Kimmeridgian. A relatively weak adakitic affinity is shown by intra-ophiolitic acid and intermediate rocks in many East Vardar provinces. It can be taken as evidence that the subduction of the young and hot slab, most likely along the earlier spreading ridge has occurred. A paleo-tectonic reconstruction consisting of four stages is proposed. It involves: a) an early/mid-Jurassic northnortheastward subduction of the West Vardar oceanic plate; b) the formation of a mid-Jurassic volcanic arc and a narrow back-arc oceanic stripe of East Vardar behind it; c) the mid-/Upper Jurassic initiation of East Vardar subduction along the ridge axis, and d) complex and heterogeneous emplacement of the East Vardar ophiolites. So far available data allow for having relatively clear ideas about the origin and evolution of the East Vardar ophiolites. However, in order to provide better understanding of all aspects of its evolution we need to answer additional questions related to the true structural position of the East Vardar ophiolites slices in Serbia, the exact nature of subduction that caused back-arc spreading (intraoceanic vs subduction under continent?) and the full significance of the adakitic signature shown by rocks in the East Vardar provinces other than Demir Kapija.
\end{abstract}

Key words: ophiolites; subduction; back-arc; Tethys; Balkan Peninsula

\section{INTRODUCTION}

It is generally accepted that geological framework of the central part of the Balkan Peninsula formed in response to the long-lasting convergence between Africa and Europe [1]. This convergence induced around $3000 \mathrm{~km}$ of shortening via consummation of vast oceanic areas and formation of many accretionary wedges and stacked nappes [2]. When studying such convergent zones it is always important to distinguish between accretionary wedges that commonly represent upper crustal levels and fundamental boundaries between underthrusting and overriding plates [3-5]. A first-order prerequisite for this distinguishing is to understand the true nature of the present ophiolite belts in sufficient details, at first place to elucidate their geodynamic affinity and the mode of emplacement. The central Balkans host three ophiolite belts that belong to a huge and complex ophiolite mega-zone stretching from the Western Mediterranean to the Himalayas, which resulted from the closure of the Mesozoic Tethys [1, 6, 7]. According to the most simplistic division (from west to east), they are: Dinaridic ophiolites (i.e., Albanian ophiolites or Pindos Zone in Albania and Greece, respectively), West Vardar ophiolites (also known as Almopias 
Zone in Greece) and East Vardar ophiolites (Peonias Zone in Greece).

The present-day understanding of the geodynamic implications of these ophiolite belts can be explained by underlying the two most important interpretations, namely the single- and the multiocean hypothesis. The single-ocean hypothesis proposed by Smith and Spray [8] (see also: [9-11], and more recently [5]), considers all ophiolite belts in the Balkan Peninsula as having originated from a single ocean - Vardar Tethys (or Neotethys). According to this view, the Vardar Tethys is directly correlated to the Meliata Ocean in the Eastern Alps and Carpathians, i.e. [12]. The advocates of the single-ocean hypothesis locate the main Neotethyan suture along the main axis of the Balkan Peninsula, along the westernmost margin of the East Vardar [5]. Simultaneously, they regard the ophiolites on both sides of this suture as having resulted from westward (Dinaridic and West Vardar) and eastward (East Vardar) obduction, respectively. Accordingly, the authors adopting the single ocean hypothesis believe that Paleozoic units that geographically separate the ophiolite belts represent progressively more distal margins of Adria, which acted as the African promontory. On the other hand, a number of other authors ([13-19], among others) argue that the ophiolite belts in the Balkan Peninsula represent remnants of distinctive oceanic domains, all of them separated by individual Paleozoic to early Mesozoic microcontinents, i.e. terranes.

These two hypotheses are principally contrasting about the nature and the origin of the western ophiolite belts and pre/early Mesozoic continental geotectonic units situated in between, whereas both groups of authors agree that the East Vardar ophiolites represent a particular ophiolite belt in many respects.

In this study, we aim to report a brief synthesis of the existing data on the East Vardar ophiolites with special emphasis on their geology and geochemical affinity. The synthesis is based on the available data on the largest and best-studied occurrences of the East Vardar ophiolites, from the South Apuseni Mountains in Romania to the very tip of the Sithonia Peninsula in Greece (see references below). The results of this synthesis confirm some of the important conclusions about the East Vardar ophiolites, suggesting a slightly refined geodynamic model and eventually argue that several aspects of the origin of these ophiolites still remain to be answered.

\section{GEOTECTONIC POSITION OF THE EAST VARDAR}

The position of the East Vardar Zone is given in a simplified geological sketch map shown in Figure 1 (modified from [20]). The most striking geotectonic feature of the East Vardar is that it structurally belongs to the westernmost margin of the predominantly eastward-facing geological units of the European plate (present coordinates), i.e. to the upper plate in the context of the final closure of the Neotethys [2]. In contrast to the westwardly situated Dinaridic and West Vardar ophiolites that appear either passively obducted over the African margin (sensu [5]; note, however, that for these two ophiolite belts they use a single name - West Vardar) or incorporated into a complex nappe stacking formed by accretion of microcontinents (sensu [19]), the East Vardar forms a narrow, several tens of kilometers wide zone that completely follows the European-derived geotectonic units of the Dacia microplate. In this context, the East Vardar has the same geotectonic position as the Circum Rhodope Belt, which is known to possess mixed AfricaEurope geotectonic affinities [21-23].

The East Vardar Zone stretches throughout the main part of the Balkan Peninsula and its rock series are exposed as a N-S line of mostly also N-S elongated outcrops that are found in Serbia, Macedonia and northern Greece and continue further south-east underneath the Aegean Sea. In the north, the East Vardar ophiolites do not follow the general trend of the Dinaridic ophiolites but are traced north-eastwards in the South Apuseni Mountains in the Mureş Valley in Romania, where they were displaced by South-Transylvanian fault [24-27].

\section{EAST VARDAR OPHIOLITES: A BRIEF SUMMARY}

In the following subsections the available data on geological and geochemical characteristics of the East Vardar ophiolites in Romania [10, 29-31], Serbia [32-36], Macedonia [33-37] and Greece $[33,38-40]$, are summarized. The locations of the ophiolite massifs/outcrops addressed in this study are shown in Figure 1. From north to south they are: South Apuseni and Transylvanian ophiolites (Romania), Ždraljica and Kuršumlija (Serbia), Guevgeli (southernmost Macedonia/northernmost Greece) and Circum Rhodope ophiolites that comprise several relatively small massifs between north from the Gulf of Thessaloniki (e.g., Oraeokastro and Thessaloniki ophiolites) and the tips of the Chalkidiki Peninsula (e.g., Kassandra and Sitho- 
nia). The ophiolites occurring more to the south in the Aegean Sea are not addressed here. In the following two subsections will be reported the main geological and geochemical features of the magmatic rocks from the above ophiolite provinces, using the division and naming given above.

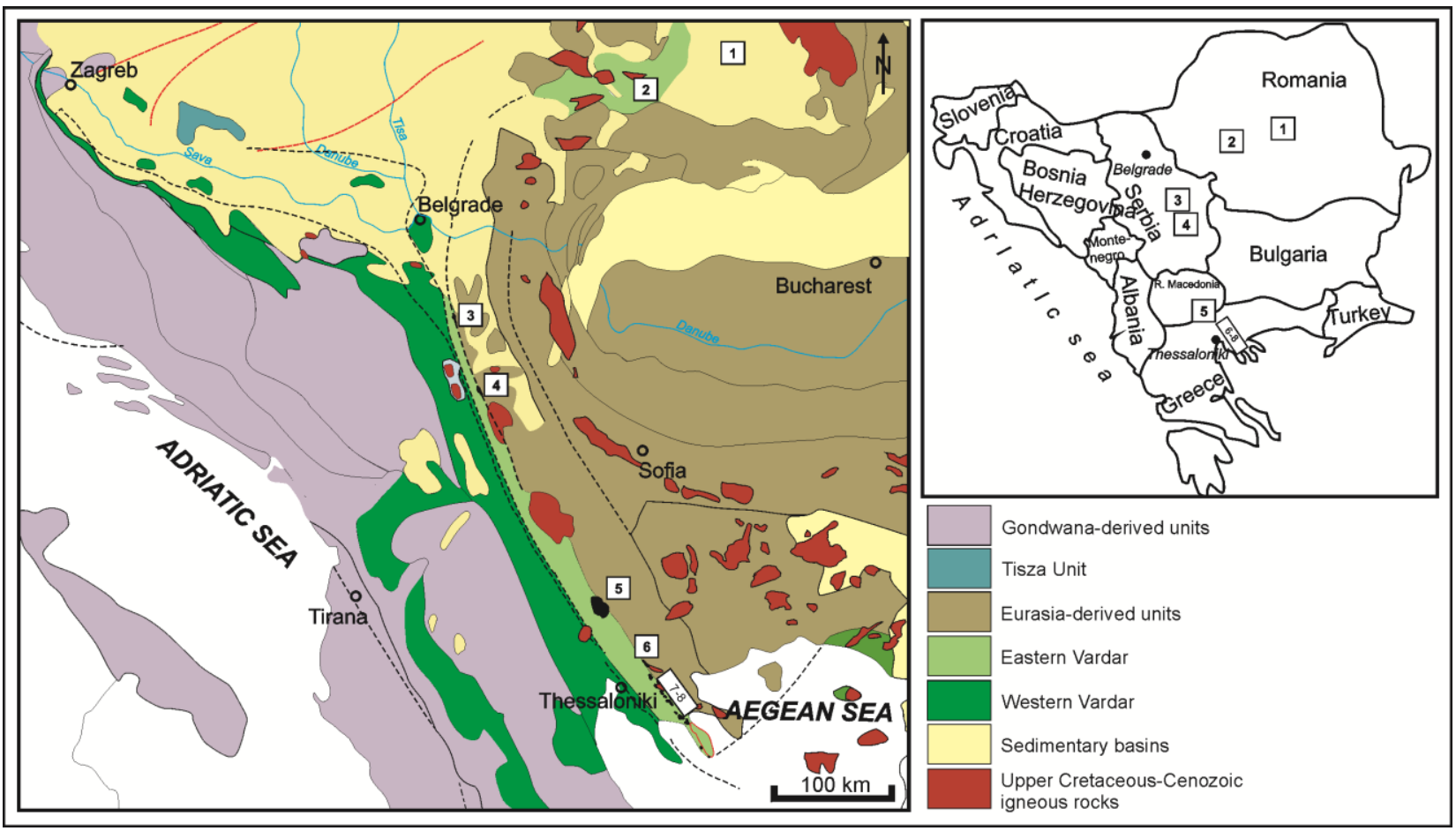

Figure 1. The geological sketch showing positions of the East Vardar provinces comprised by this study. The sketch is a simplified version of the geological sketch of South-East Europe [20] and represents a compilation of the Geological Atlas of Serbia 1:2,000,000 [28] and of the tectonic map 1:5,000,000 [5]; 1 - Transylvanian ophiolites (drill holes), 2- South Apuseni ophiolites, 3 - Ždraljica ophiolites, 4 - Kuršumlija ophiolites, 5 - Guevgeli ophiolites, 6 - Oraeokastro ophiolites, 7-8 - Thessaloniki-Chalkidiki ophiolites).

\section{Geology}

The northernmost occurrences of the East Vardar ophiolites are located in the South Apuseni Mountains (for details see: [27, 29, 31]). It is a pile of nappes composed of the Biharia basement that represents counterparts of the Supragetic unit (i.e., Serbo-Macedonian Massif sensu [5]). The basement is overlain by Late Cretaceous clastic sediments and the entire section is tectonically overlain by the Mureş nappe that includes the East Vardar Middle Jurassic ophiolites. The ophiolites consist of a gabbroic complex overlain by a sheeted dyke and volcanic sequence that includes massive lava flows and pillow-lavas. The latter are spatially associated to Callovian - Oxfordian radiolarians. The mafic ophiolite members are intruded by calcalkaline granitoids and covered by a calc-alkaline volcanic series composed of basalts, basaltic andesites, andesites, dacites and rhyolites. The overstep sequence is on the top and is represented by Late Jurassic shallow-water limestones showing the transition to Cretaceous carbonate deposits. The U$\mathrm{Pb}$ ages of mafic ophiolites members and accompanying intra-ophiolite granitoids revealed similar ages 158.9-155.9 Ma and 158.6-152.9 Ma, respectively [31].

The presence of analogous ophiolitic rocks is indirectly revealed by deep wells in the Transylvanian Depression [30]. A few of the wells drilled the Middle/Upper Jurassic volcanic rocks ranging in composition from basalts to andesite are interpreted to represent counterparts of the calc-alkaline series that overlies the South Apuseni Mountains ophiolites. The presence of underlying ophiolites is only inferred by geophysical data [30].

The East Vardar ophiolites in Serbia are represented by two relatively small and elongated massifs of Ždraljica and Kuršumlija [32, 41, 42]. They occur as up to $20 \mathrm{~km}$ long and only several $\mathrm{km}$ wide NNW-SSE aligned outcrops that are in tectonic contacts with the mid- to Upper Jurassic mélange and high/medium-grade meta-igneous and metasedimentary rocks of the Serbo-Macedonian 
Massif. The contacts between the ophiolites and the Serbo-Macedonian Massif are at places sealed by Neogene sediments [43]. In [35], 2D modelling of gravity and magnetic data and pseudo-3D modelling on the East Vardar ophiolites in Serbia were reported and it was suggested that they are dipping to the east beneath the Serbo-Macedonian Massif. The age of these ophiolites is mostly geologically constrained by the age of the overstep sequence represented by Tithonian reef limestone and/or flysch-like Lower Cretaceous sedimentary rocks [44-46]. The Serbian East Vardar ophiolites are predominantly composed of series of basic igneous rocks, whereas ultramafic members are almost absent. The Ždraljica complex is represented by cummulitic gabbros in the form of irregularly shaped bodies. The gabbro bodies are cut by isolated shallow intrusive dolerites, which at some places appear as relicts of sheeted-dyke series. Pillow basalts are substantially rare. The Kuršumlija complex contains more abundant dolerite dykes and 5$10 \mathrm{~m}$ thick series of pillow lavas. It is worth noting that in both ophiolite complexes occur numerous shallow intrusive and subordinate volcanic rocks of acid to intermediate compositions.

The largest exposure of the East Vardar ophiolites is the Guevgeli complex. In the east, the Guevgeli complex is in tectonic contacts with the Serbo-Macedonian Massif forming a narrow mylonitic-phyllitic zone. In the west, it is in contact with the metamorphic rocks of the Paikon unit that consists of Triassic marbles, clastic sediments, micaschists and various Upper Jurassic volcanic rocks that range in composition from rhyolite to basalt [47-49]. The northern part of the Guevgeli complex is the Demir Kapija ophiolites [33, 34, 37]. It is situated in southernmost Macedonia as an NNW-SSE elongated, $50 \mathrm{~km}$ long and $25 \mathrm{~m}$ wide and partially dismembered belt. It is transgressively covered by conglomerates overlain by Upper Tithonian reef limestones [50] that are themselves covered by Palaeogene-Neogene sediments. The structural position of the Demir Kapija ophiolites is also inferred by 2D and pseudo-3D geophysical modelling, which suggests that they have a very steep contact that dips towards the east-southeast under the Serbo-Macedonian Massif [36]. The Demir Kapija ophiolite is predominantly built of volcanic rocks, although small serpentinite blocks occur within tectonic mélange near Rabrovo [51]. The volcanic-intrusive series of Demir Kapija is represented by pillow lavas, diabase dyke swarms and gabbros of variable grain-size. Small serpentinized chromite-bearing dunite, wehrlite and lherzolite are very subordinate. The complex also con- tains numerous small-scale ( $<5 \mathrm{~m}$ thick) shallow intrusions of acid to intermediate compositions. In the both northern and southern part of the complex, however, occur much larger granitoid intrusive bodies, such as Štip, Konče, Gradeške Mts. and Plauš-Furka-Fanos, some of them covering more than $70 \mathrm{~km}^{2}$. These granitoids cut the basement and are, therefore, considered as post-ophiolite intrusions [52]. Božović et al. [37] reported U/Pb zircon age for gabbros of Demir Kapija at $166 \pm 1.8 \mathrm{Ma}$ constraining the age of the oceanic crust, which agrees well with Bathonian-Callovian radiolarian [53]. It is also obtained only a slightly lower age of $164 \pm 0.5 \mathrm{Ma}$ for presumably younger subductionrelated rocks by Ar/Ar analyses of feldspars [37].

These ophiolites continue southwards across the Macedonian-Greek border and form two branches. The western one is known as the Skra ophiolite which is composed of cummulitic olivine- and isotropic normal gabbros as well as of an extrusive sequence consisted of massive lavas and dykes accompanied by felsic shallow intrusives; ultramafic rocks are extremely rare [54]. Spray et al. [55] reported ${ }^{40} \mathrm{Ar} /{ }^{39} \mathrm{~K}$ ages on biotite and kaersutite mineral separates from gabbros and diorites between $149 \pm 3 \mathrm{Ma}$ and $163 \pm 3 \mathrm{Ma}$. Danelian et al. [56] studied radiolarians from the overstep sequence and determined Oxfordian age (161.2155.7 Ma). Zachariadis [38] studied zircons from plagiogranite found in gabbros of the Skra complex and reported an intrusion age of $166.6 \pm 1.8 \mathrm{Ma}$. The Evzonoi ophiolites occur in the east and are entirely composed of massive and pillow lavas and dolerite dyke swarms. The sheeted dyke sequence is frequently cut by rocks of rhyolite composition that make sharp contacts towards the adjacent mafic rocks and sometimes even enclose them as xenoliths. Apart of these small-scale felsic intrusions, the Skra and Evzonoi ophiolites are intruded by a much larger $\left(\sim 65 \mathrm{~km}^{2}\right)$ granitoid intrusion of Fanos, presumably representing the continuation of the Plauš-Fourka granitoid in the southernmost Macedonia [33]. Anders et al. [49] reported an $\mathrm{U} / \mathrm{Pb}$ age of the Fanos granitoid of $158 \pm 1 \mathrm{Ma}$. Zachariadis [38] argued that the Fanos granitoid intruded the Guevgeli ophiolites after their emplacement and reported the presence of, albeit rare, occurrences of mafic dykes that intrude the Fanos granite.

Further to the south the East Vardar ophiolites occur as a lineament of more than ten isolated ophiolite slices hereafter collectively named the Circum Rhodope ophiolites. The first is Oraeokastro ophiolite that crops out as an NW-SE elongated $(2.5 \times 12 \mathrm{~km})$ slice situated $\sim 5 \mathrm{~km}$ northern of Thessaloniki. In the east, the Oraeokas- 
tro ophiolite is in contact with phyllites and Triassic limestones, whereas the latter tectonically overlie the ophiolite. According to Zachariadis [38], the phyllite represents ophiolitic material that was milonitized during overthrusting of the limestone. In the west, the ophiolite is transgressively covered by Tithonian fossiliferous conglomerate in which pebbles of ophiolitic origin occur [22, 47]. Ultramafic rocks appear as a small body of $2-3 \mathrm{~km}$ north-east from the main ophiolite slice and is represented by harsburgite tectonite. The margins of this isolated body are sheared. Mafic shallow intrusives are found cutting gabbros and as relicts of sheeted dykes. Extrusive ophiolite rocks are rare and mainly occur along the western border. They are composed of massive and/or pillow lavas and accompanied hyaloclastite deposits. Felsic rocks are common and are found as dykes and irregular lenses inside the series of mafic rocks.

The Thessaloniki ophiolite is represented by a volcanic ophiolite sequence that was excavated during the civil engineering activities along the north-eastern periphery of the city. Gabbros that occur in a wider area were poorly known and were not even considered as a part of an ophiolite [21, 22, 5759]. The Thessaloniki ophiolite predominantly consists of dolerite dykes and subordinate lavas, mostly massive and rarely as pillows as well. Hornblende gabbro from Thessaloniki ophiolite was dated by $\mathrm{K} / \mathrm{Ar}$ method at $174 \pm 4.8 \mathrm{Ma}$ [60] (details are lacking). Zachariadis [38] reported a zircon (one crystal) age on a diorite (outskirts of the city of Thessaloniki) as a concordia of $169 \pm 1 \mathrm{Ma}$, and interpreted as the crystallization age of the diorite. He also dated a diorite from the Chortiatis magmatic suite and obtained an age of $159 \pm 4 \mathrm{Ma}$, which demonstrated that the Chortiatis magmatic suite is younger than Thessaloniki ophiolite for around $10 \mathrm{Ma}$.

The southernmost outcrops of the East Vardar ophiolites of the Greek shoreline are represented by the Chalkidiki ophiolites. They crop out as several dismembered slices. The largest are along the southernmost edges of the Kassandra and Sithonia peninsulas. The Kassandra ophiolites are in contact with younger rocks exclusively, i.e. they are covered by an overstep sequence of Cretaceous/Upper Jurassic limestones and by a thick series of Cenozoic sediments. The ophiolites are represented by mafic extrusive rocks ([61], and references therein), mainly as variably vesicular massive lavas and rarely pillows. The Sithonia ophiolites outcrop as elongated slices that have tectonic contacts with the Eocene Sithonia granite [62,63] and the Triassic to Middle Jurassic Svoula flysch [64]. In the south, the ophiolites are covered by Upper
Jurassic reef limestones. The Sithonia ophiolite is represented by series of mafic magmatic rocks that appear as thin stripes along the south and southwest shoreline as well as offshore on small islands (e.g. Kelyfos). It is an extrusive sequence with extremely well-preserved pillow lavas at some places, and sometimes associated with feeding dykes or rarely with dyke swarms. More to the south, including the very tip of the peninsula (e.g. Cape Laemos) deeper ophiolite members represented by coarse- to medium-grained gabbro, at some places cut by hornblendite veins, occur. Zachariadis [38] reported $\mathrm{U} / \mathrm{Pb}$ zircon ages for gabbro-diorite/diorite rocks from two places of the Chalkidiki ophiolites: namely from the Metamorphosis area and from Sithonia. Zircons from the Metamorphosis yielded a concordia age of $165.3 \pm 2.2 \mathrm{Ma}$ whereas those from Sithonia gave an average age of $160 \pm 1.2 \mathrm{Ma}$.

\section{Rock geochemistry}

Geochemical characteristics of the magmatic member of the East Vardar ophiolite provinces are summarized and illustrated in Figures 2-5. The synthesis was restricted to volcanic and subvolcanic basic $\left(\mathrm{SiO}_{2}<55 \%\right)$ as well as intrusive ( \pm volcanic) acid/intermediate rocks $\left(\mathrm{SiO}_{2}>55 \%\right)$, which compose the above described ophiolites (the references are listed above and in caption for Figure 2). The analyses of peridotite rocks and cummulitic gabbros are omitted from further consideration.

$\mathrm{The} \mathrm{Nb} / \mathrm{Y}$ vs $\mathrm{TiO}_{2} / \mathrm{Zr}$ diagram commonly used for classification of magmatic rocks occurring in ophiolitic sequences is shown in Figure 2 [65]. It reveals that most East Vardar basic rocks (dotted symbols) stretch across the fields of subalkaline basalts and basaltic andesites, and that they mostly compositionally overlap with the field occupied by the basic rocks of West Vardar ophiolites (pink area). However, in all the studied East Vardar provinces occur abundant acid to intermediate rocks represented by calc-alkaline volcanic, subvolcanic or typical intrusive rocks (open symbols). This is different from the West Vardar ophiolites in which acid to intermediate rocks are substantially rare (see also the inset that shows the total alkali vs silica diagram [66]). The Upper Jurassic granitoids occurring in southernmost Macedonia (e.g. Štip, Dolane, Konče, etc.) and northernmost Greece (Fanos) are spatially associated to the Guevgeli ophiolite complex but are plotted with separate symbols (red dots). They have so far been interpreted as intrusions into both the East Vardar ophiolites and the basement rocks, and, therefore, we intended to distinguish them from other typically intra-ophiolitic acid to intermediate rocks of the Guevgeli complex. 


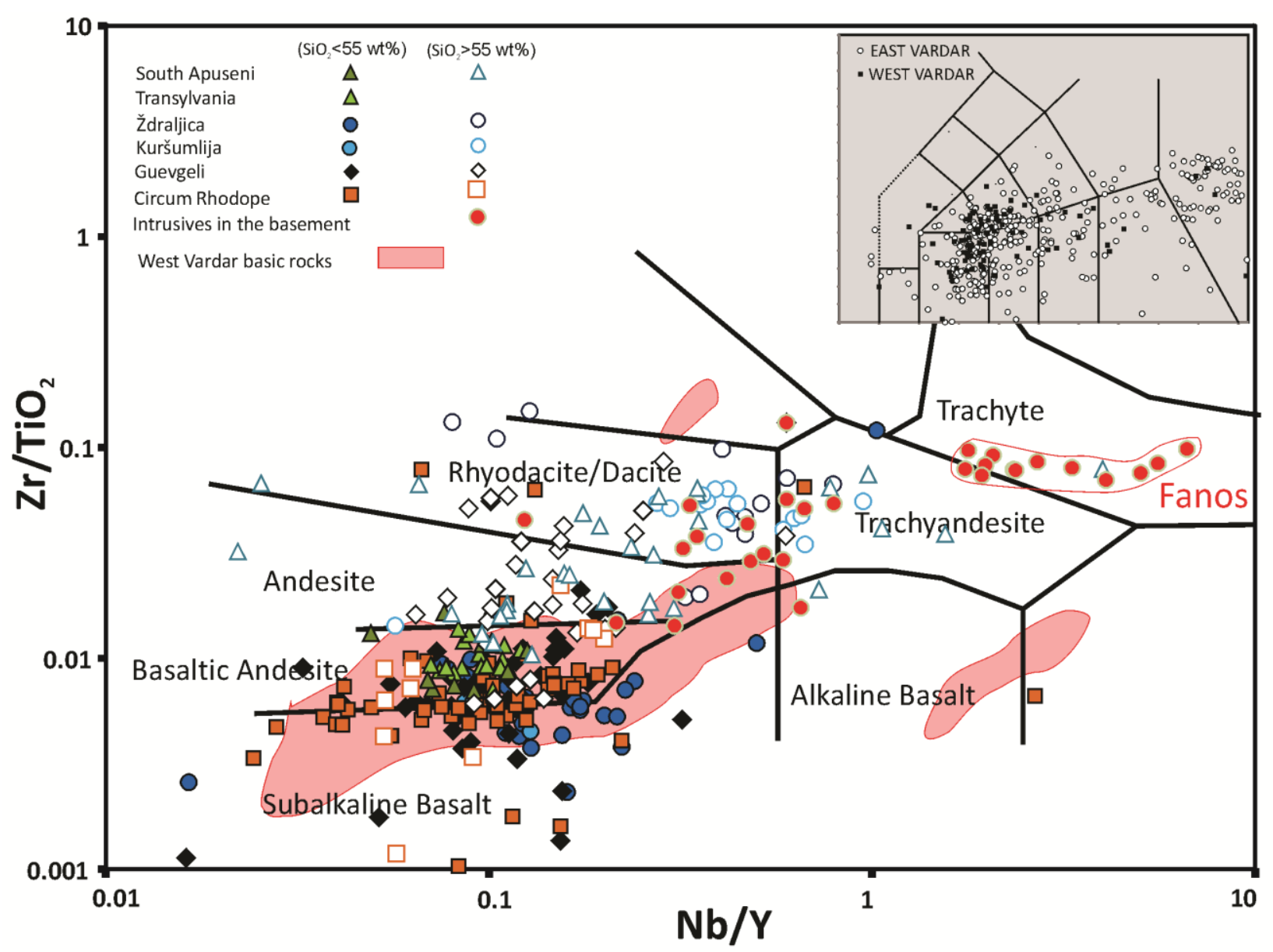

Figure 2. $\mathrm{Nb} / \mathrm{Y}$ vs $\mathrm{Zr} / \mathrm{TiO}_{2}$ classification diagram [65]; the inset shows the distribution of all the bulk rock analyses comprised by this study on the total alkali vs silica (TAS) diagram [66]. Data sources: South Apuseni - [10], [31]; Transylvania - [30]; Ždraljica and Kuršumlija - [32-34]; Guevgeli - [37-39]; Circum Rhodope - [38, 40]; Intrusives in the basement - [33]; West Vardar basic rocks - [17, 34, 67, 68].

It is evident, however, that these granitoids believed to cut the metamorphic basement also form two different subgroups. For instance, the Fanos samples are plotted towards high $\mathrm{Nb} / \mathrm{Y}$ values (>1) (Figure 2).

Primitive mantle-normalized multielement and chondrite-normalized rare earth elements (REE) diagrams are shown in Figures 3 and 4, respectively. The rocks from all the studied ophiolite provinces are also subdivided into basic $\left(\mathrm{SiO}_{2}<\right.$ $55 \%$; diagrams in the left) and acid/intermediate $\left(\mathrm{SiO}_{2}>55 \%\right.$; diagrams in the right) rocks. The basic rocks range from light-rare earth elements (LREE) enriched through relatively flat REE patterns to LREE depleted chondrite-normalized patterns and almost ubiquitously show troughs on $\mathrm{Nb}$ Ta and often, but less pronounced on Ti as well as peaks on U-Th on primitive mantle-normalized diagrams. These characteristics are different from those shown by the basic rocks of the West Vardar ophiolites, which exhibit much smoother primitive mantle-normalized patterns.
In keeping with their more evolved character, the intermediate/acid rocks of the East Vardar display more pronounced crustal geochemical signature. This is evident from LREE-enriched chondrite-normalized pattern often with negative Euanomaly as well as from large ion lithophile elements (LILE)-enriched and $\mathrm{Nb}$-Ta-Ti-depleted spiked patterns on primitive mantle-normalized diagrams. It is noteworthy that these acid/intermediate rocks display a relatively wide range of heavy REE (HREE) concentrations, ranging from < $2 \times$ chondrite to around $10 \times$ chondrite values. Božović et al. [37] reported the presence of Y-and HREE-depleted acid/intermediate rocks from the Demir Kapija ophiolites and interpreted them as having adakitic affinity using this as an important argument for suggesting a refined geodynamic interpretation. The occurrence of rocks of similar adakitic-like geochemical affinity has been reported in Serbia by Sarić et al. [33], but these rocks have not been given a strong geodynamic significance. 

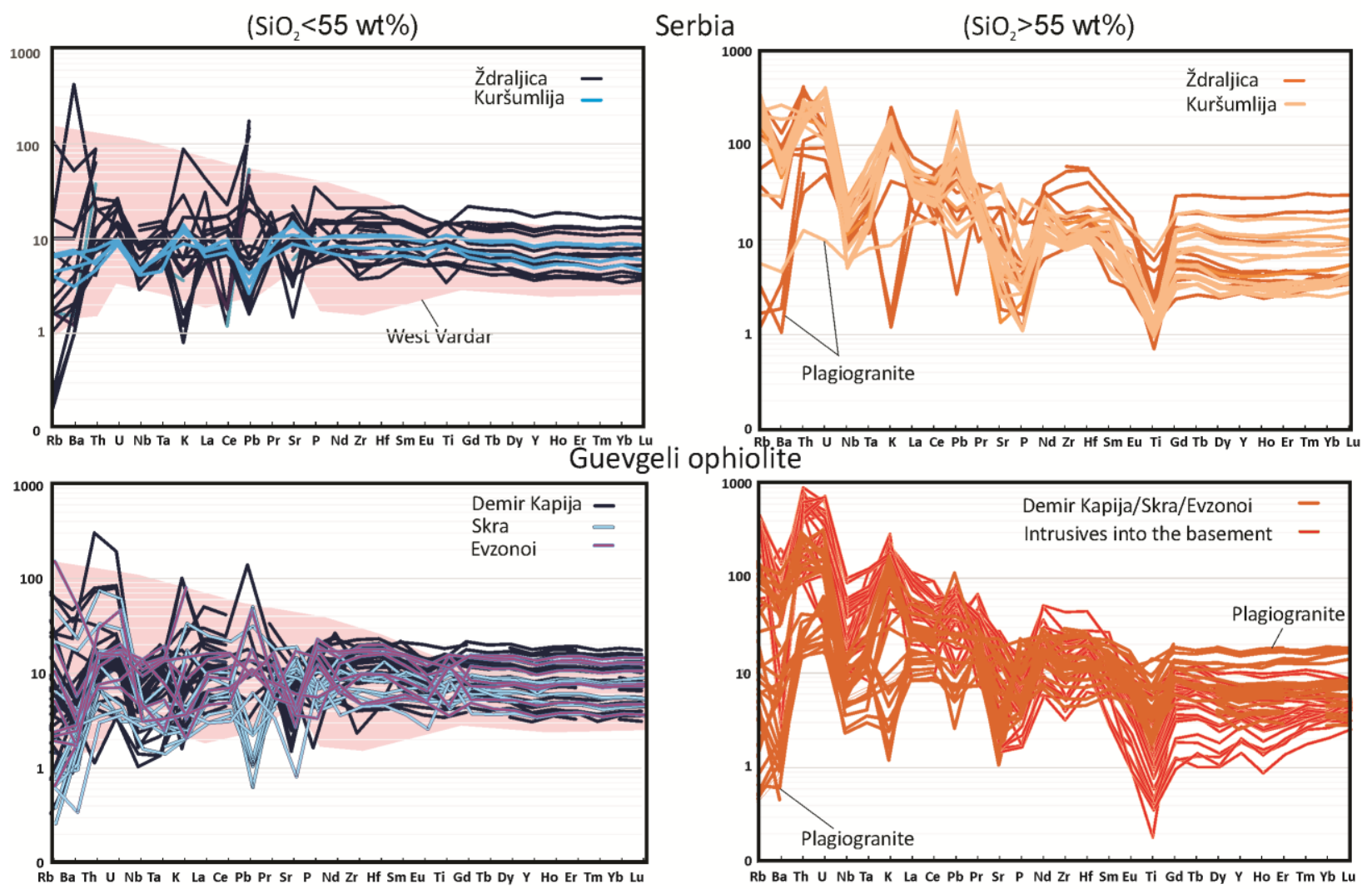

Circum Rhodope ophiolites
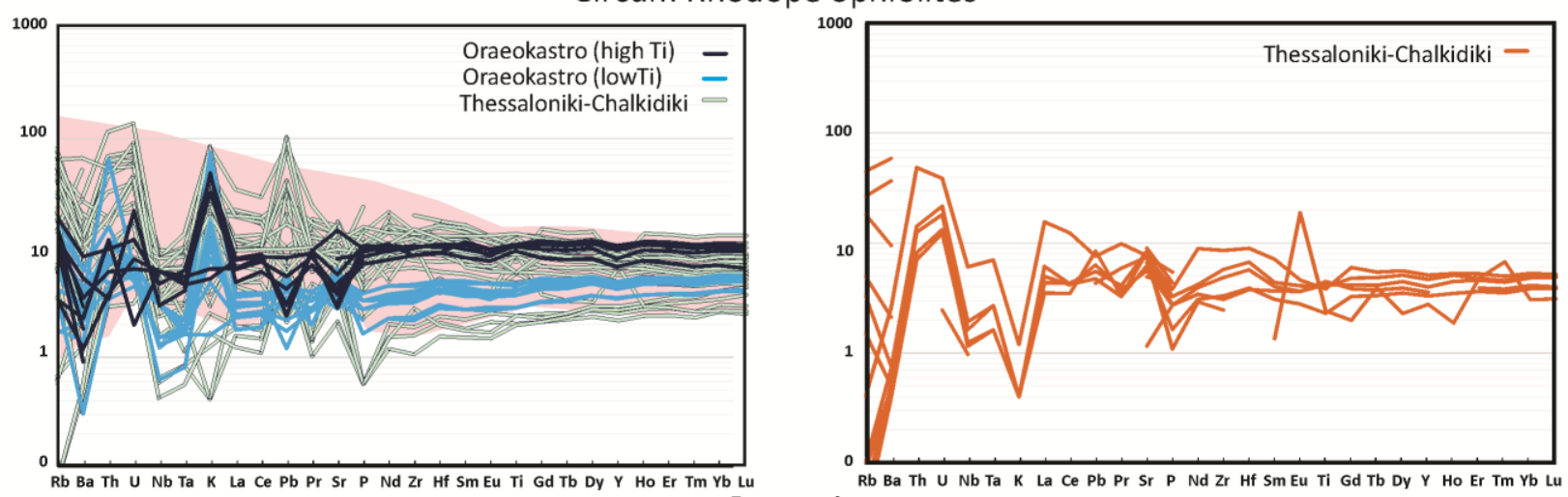
Romania
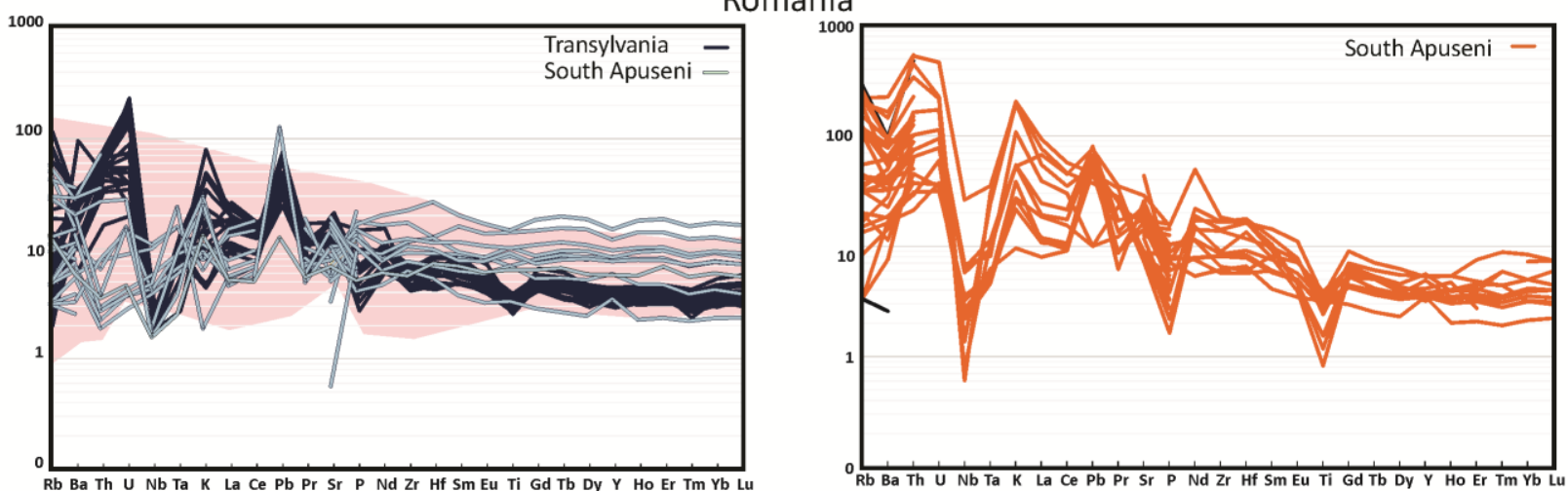

Figure 3. Primitive mantle-normalized multielement diagrams for the East Vardar magmatic rocks; the normalization coefficients after [69]. See capture in Figure 2 for data sources. 

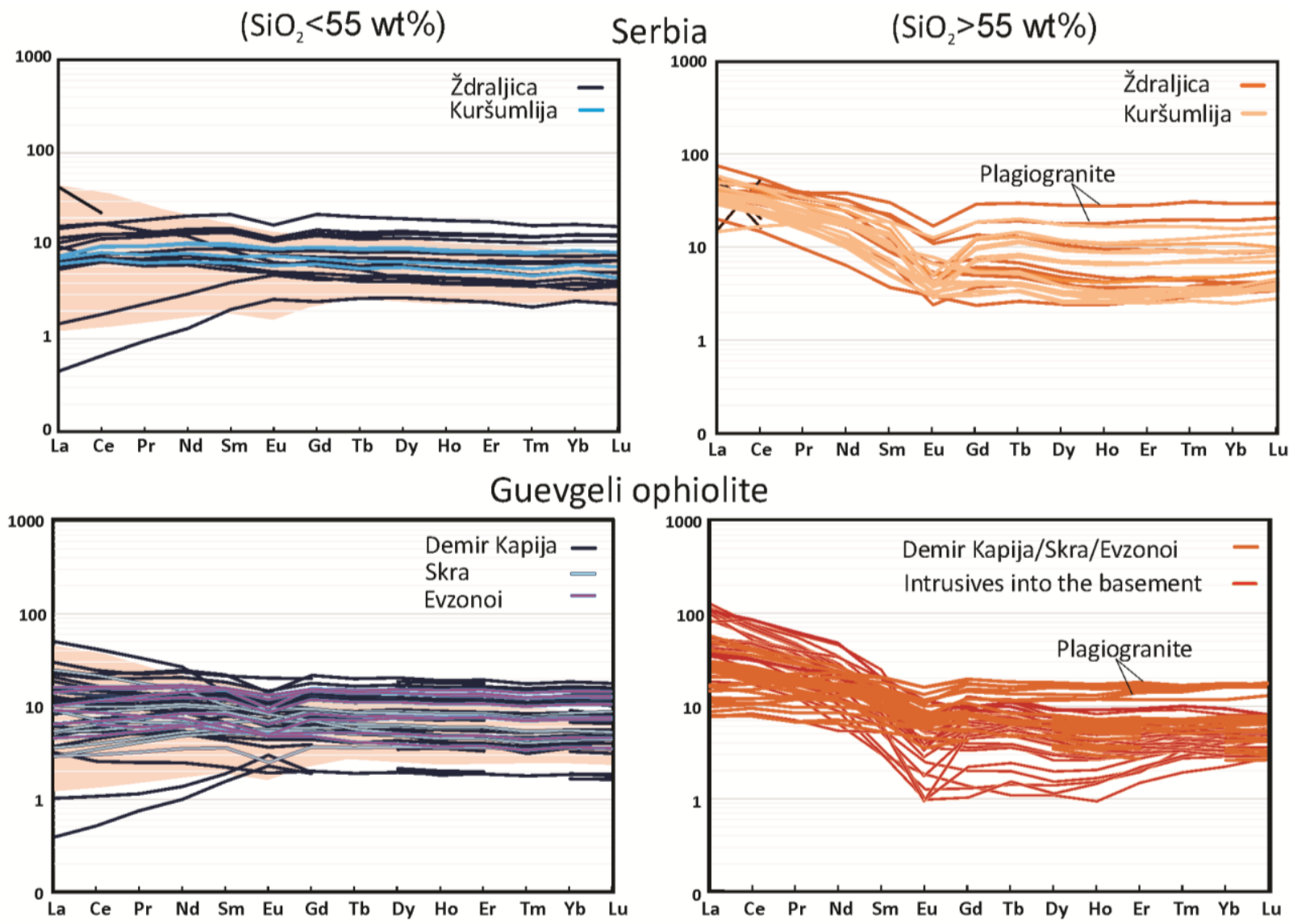

Circum Rhodope ophiolites
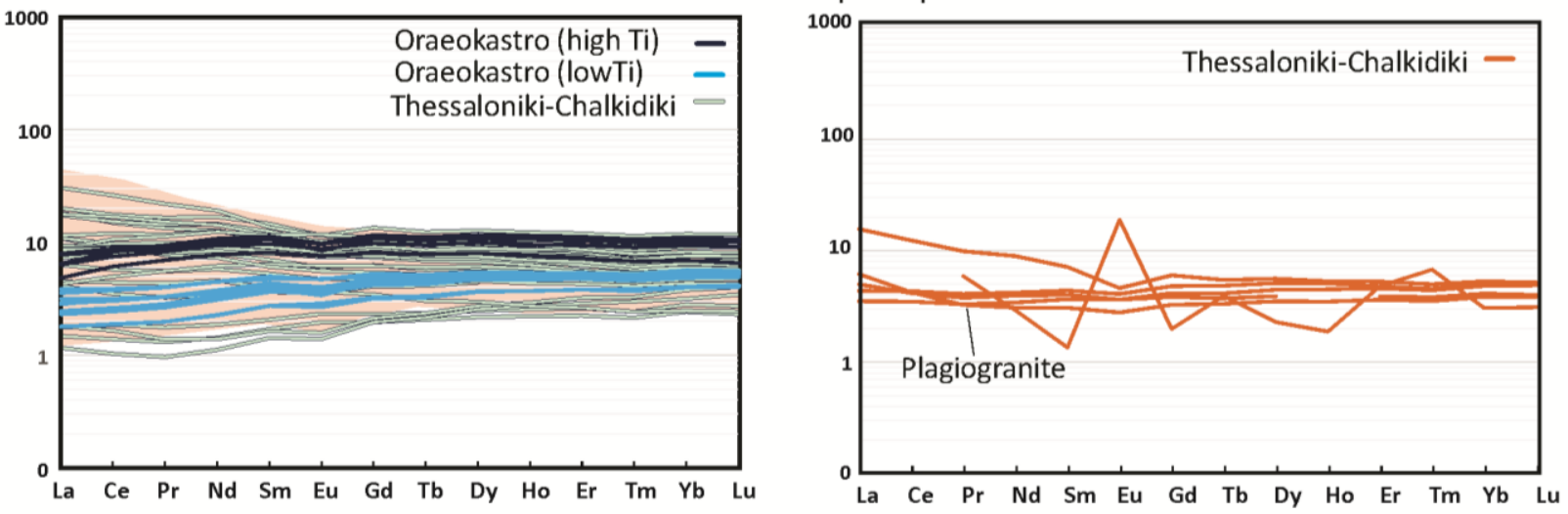

Romania
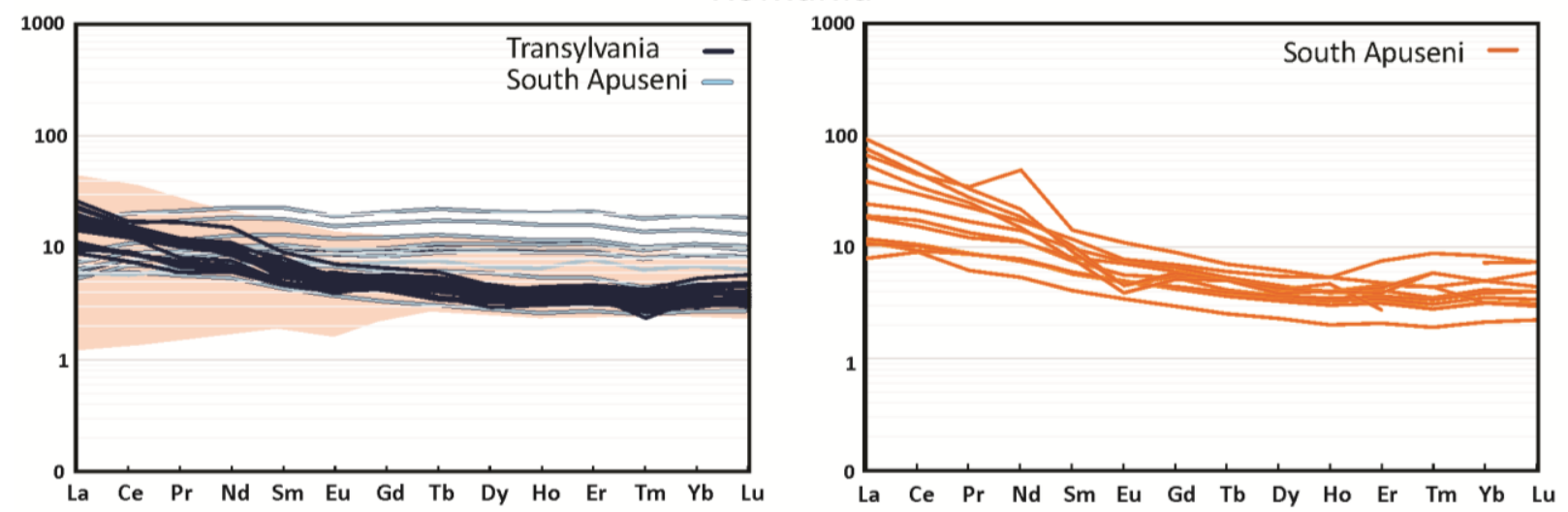

Figure 4. Chondrite-normalized REE diagrams for the East Vardar magmatic rocks; the normalization coefficients after [69]. See capture in Figure 2 for data sources. 
Note also that a few silica-rich samples are characterized by relatively flat REE patterns as well as by high absolute heavy REE concentrations and low LILE concentrations, and they most probably represent oceanic plagiogranites. These acid rocks are not considered in the further discussion.

Sr-Nd compositions of the studied rocks are shown in Figure 5. It can be seen that the basic rocks of most provinces the East Vardar overlap in $\mathrm{Sr}-\mathrm{Nd}$ isotopic composition and display somewhat higher ${ }^{87} \mathrm{Sr} /{ }^{86} \mathrm{Sr}$ and lower ${ }^{143} \mathrm{Nd} /{ }^{144} \mathrm{Nd}$ isotopes in comparison to the basic rocks of the West Vardar ophiolites. In terms of Sr-Nd isotopes, among the ophiolite-related acid/intermediate rocks of the East Vardar, at least two groups can be distinguished. The first group (rectangle in Figure 5) partly overlaps with or is only slightly enriched in $\mathrm{Sr}$ and depleted in $\mathrm{Nd}$ isotopes than the accompanying basic rocks. The second group of acid/intermediate rocks plots towards the enriched quadrant of the diagrams and is characterized by a relatively continuous and steady increase in ${ }^{87} \mathrm{Sr} /{ }^{86} \mathrm{Sr}$. Although the strong increase in $\mathrm{Sr}$ isotope ratios can be partly explained by seawater alteration processes (see also [34]), there is less pronounced but also a continuous increase in ${ }^{143} \mathrm{Nd} /{ }^{144} \mathrm{Nd}$ isotope ratios shown by these rocks, suggesting that these variations must be related to the input of crustal material in the mantlederived melts. These isotopically crustal-like granitoids form two subgroups, initially recognized in [33] as low $\mathrm{Sr} i\left({ }^{87} \mathrm{Sr} /{ }^{86} \mathrm{Sr}_{\text {initial }} \sim 0.7033-0.7076\right)$ and high $\mathrm{Sr} i\left({ }^{87} \mathrm{Sr} /{ }^{86} \mathrm{Sr}_{\text {initial }}>0.7095\right)$. To the low Sri belong all intra-ophiolitic granitoids of Ždraljica, part of the Kuršumlija intrusives and the samples of the Fanos granitoids, whereas the rest of the Kuršumija samples and all the granitoids from Macedonia that intrude the basement belong to the high Sri group.

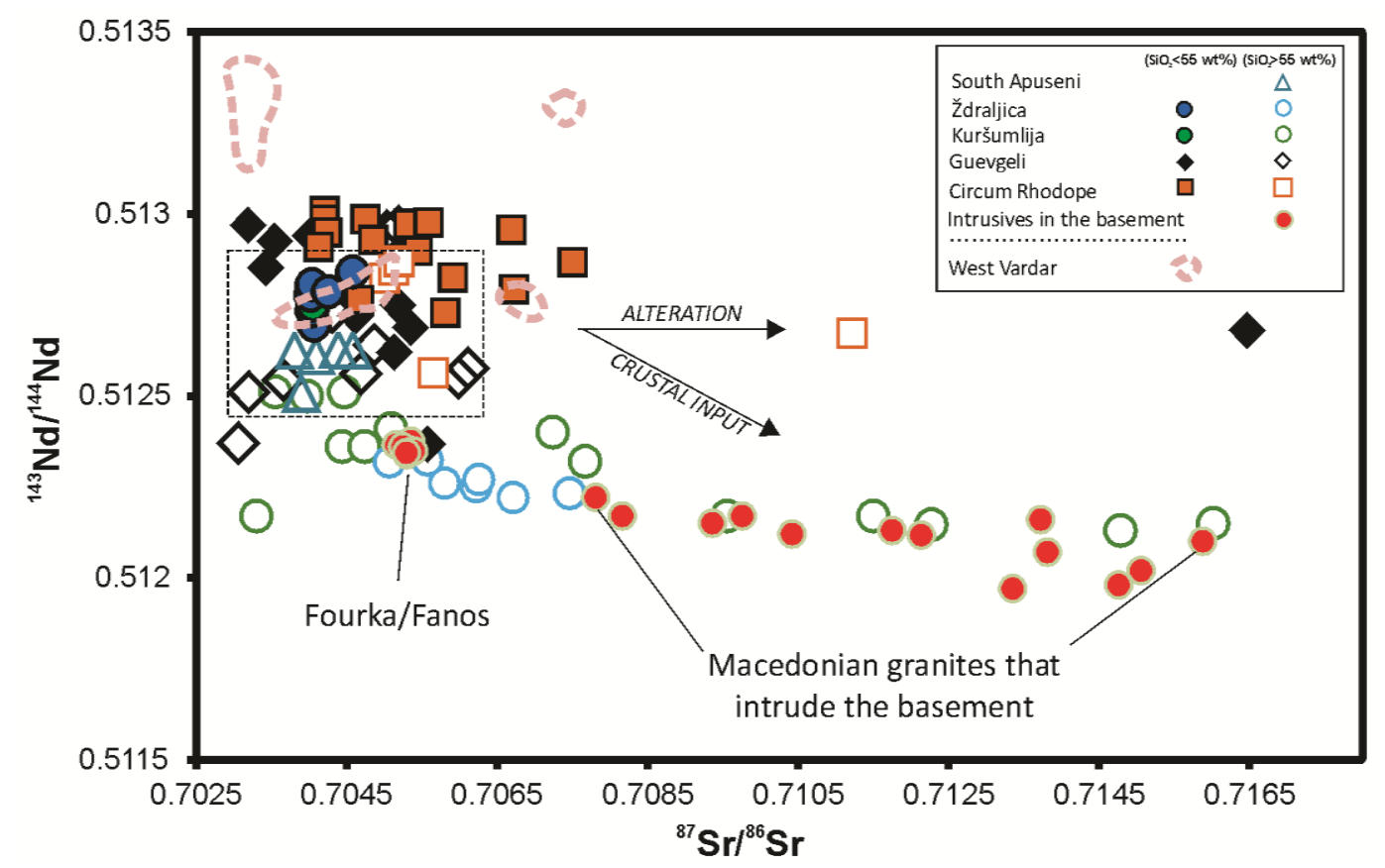

Figure 5. The ${ }^{87} \mathrm{Sr} /{ }^{86} \mathrm{Sr}$ vs ${ }^{143} \mathrm{Nd} /{ }^{144} \mathrm{Nd}$ plot for the East Vardar magmatic rocks; the rectangle encloses the field of the East Vardar acid/intermediate rocks that overlap in $\mathrm{Sr}-\mathrm{Nd}$ isotopic composition with the majority of the accompanying basic rocks. See capture in Figure 2 for data sources.

\section{DISCUSSION}

The above presented overview of the most important geological and geochemical characteristics exhibited by the magmatic rocks of the East Vardar Zone ophiolites allows for recognition of several mutual features that can be underlined. They are related to the structural and stratigraphic position, age, rock facies, and the rocks' geochemical affinity. In the following sections, we summa- rize this information again in order to underline those issues that are most important and provide the first order geodynamic implications.

\section{Tectonostratigraphy and age}

Most here addressed East Vardar ophiolite slices are elongated in N-S direction (present coordinates) and are in tectonic contacts with metamorphic rocks of the Serbo-Macedonian Massif. The 
only exceptions are the South Apuseni ophiolites that presently stretch E-W due to substantial $\left(\sim 90^{\circ}\right)$ clockwise rotations in the Cenozoic [70, 71]. The South Apuseni ophiolites lay upon the Biharia basement, which is considered part of the westernmost margin of Dacia, i.e. the Supragetic unit or the counterpart of the Serbo-Macedonian Massif [5]. The contacts between the East Vardar ophiolites and the Serbo-Macedonian Massif change towards the south. Recent geophysical modelling suggests that the contacts between the East Vardar ophiolites in Serbia and Macedonia and the Serbo- Macedonian Massif are steeply dipping and that at least some parts of the East Vardar ophiolites dip eastwards beneath the Serbo-Macedonian Massif [35, 36]. In this area, the contact between the East Vardar and Serbo-Macedonian unit is usually marked by the presence of narrow stripes of strongly deformed phyllites that sometimes contain serpentinite blocks [51]. This structural position is in agreement with the observations that the East Vardar ophiolites are thrust westwards onto the metamorphic rocks of the Paikon block or its counterparts [38, 39, 72]. Further to the south, the East Vardar ophiolites are strongly dismembered and appear as individual blocks within highly heterogeneous Circum Rhodope Belt.

The geologically and radiometrically constrained ages of the East Vardar ophiolites are recently comprehensively summarized by Gallhofer et al. [31]. They concluded that the maximal emplacement (obduction) age of the East Vardar ophiolites is the uppermost Kimmeridgian $(<152 \mathrm{Ma})$, which is in agreement with the geological evidence, i.e. by the fact that the ophiolites are commonly covered by Tithonian limestones or Lower Cretaceous clastic sediments (e.g., [50]). It is worth noting that the presumed crystallization ages of mafic members of these ophiolites are mostly younger than $165 \mathrm{Ma}$ and that there is no substantial age difference between the mafic and acid/intermediate members, which suggests that this oceanic realm was rather short-lived, i.e. it underwent a relatively fast evolution from ocean floor spreading to subduction and obduction processes [31, 37, 38, 40].

\section{Subduction geochemical affinity shown by the basic rocks}

The East Vardar ophiolites, in general, share two striking petrological characteristics: i) they are predominantly composed of volcano-intrusive sequences, whereas serpentinized peridotites are very scarce, and ii) in most of the East Vardar ophiolite provinces occur abundant acid to intermediate volcanic and/or intrusive rocks. The basic volcanic and shallow intrusive rocks of the East Vardar are generally similar to those of other Balkan ophiolites (see Figures 2-7), but the magmatic rocks of the East Vardar ophiolites are consistently more LREEand sometimes LILE-enriched and plot towards enriched isotopic composition in the Sr-Nd space, which suggests that subduction processes have likely been involved in their origin.

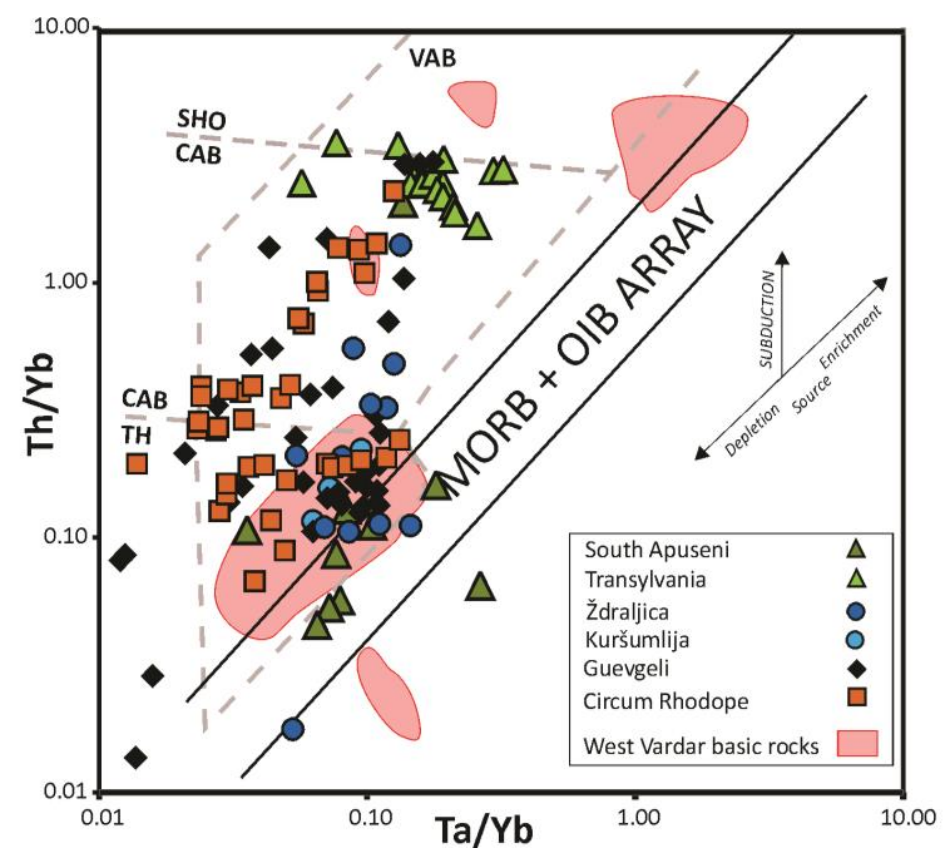

Figure 6. The $\mathrm{Ta} / \mathrm{Yb}$ vs $\mathrm{Th} / \mathrm{Yb}$ plot for distinguishing primitive basaltic magmas formed by subduction processes [73]. See capture in Figure 2 for data sources. 


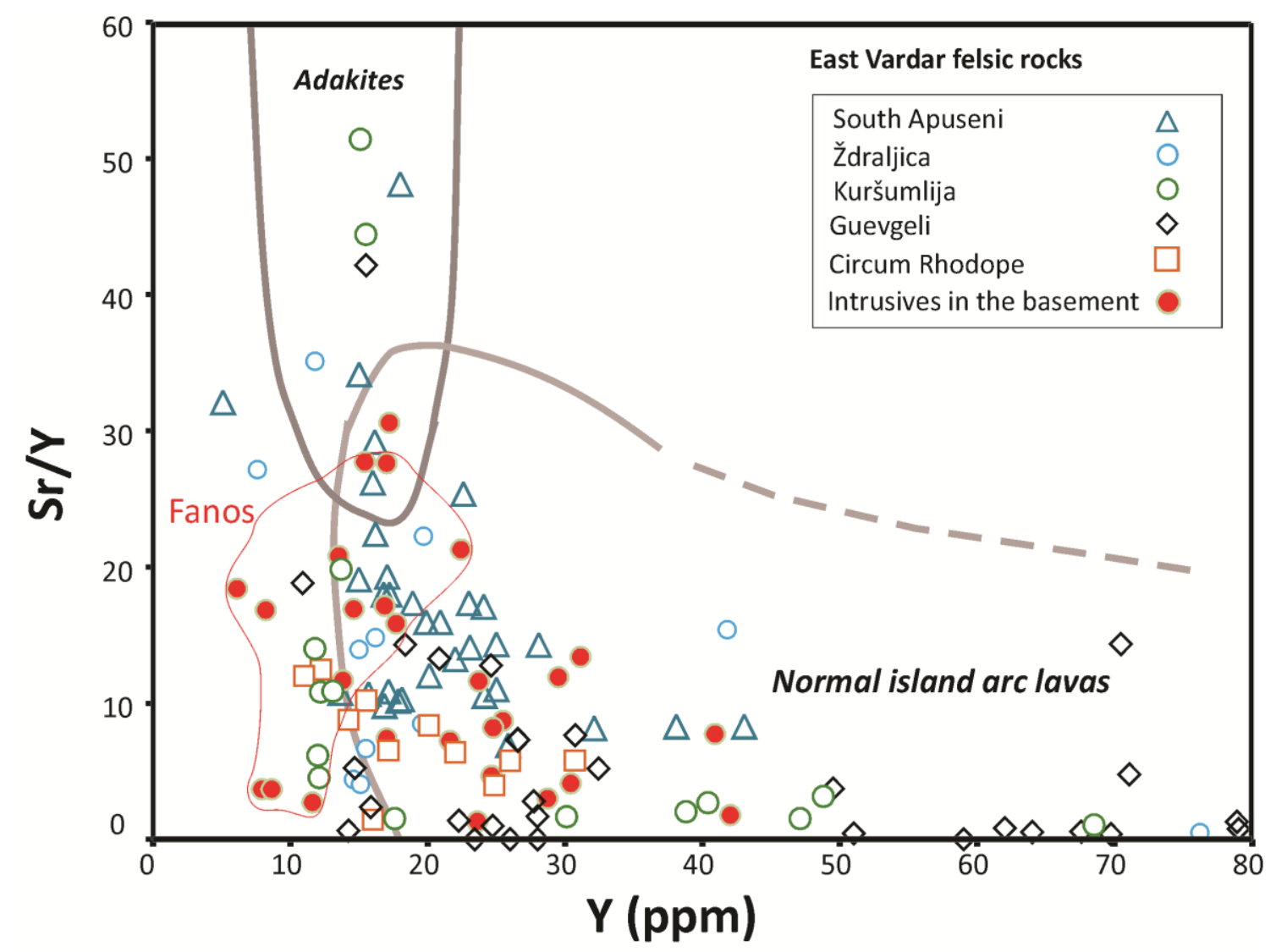

Figure 7. The $\mathrm{Y}$ vs Sr/Y plot for distinguishing between normal arc magmas and those having adakitic geochemical signature [75]. See capture in Figure 2 for data sources.

The subduction-related affinity (island arc or back-arc) of the rocks from many East Vardar occurrences have so far suggested by many authors (e.g., [31, 33, 37, 39], among others). Here we illustrate this affinity by using the $\mathrm{Ta} / \mathrm{Yb}$ vs $\mathrm{Th} / \mathrm{Yb}$ diagram [73] that is commonly applied for distinguishing the involvement of subduction-related enrichments from the source enrichments unrelated to active margin processes. From the diagram shown in Figure 6 it is evident that most ophiolite-related basic rocks of the East Vardar depart from the midocean ridge - ocean island basalts array and plot towards the area characterized by increased $\mathrm{Th} / \mathrm{Yb}$ ratios. This can be explained by involvement of subduction fluids plus a certain amount of sediments in melting regions from which these primary melts originated (e.g. [74]).

\section{The message provided by the composition of felsic rocks}

The above discussed subduction affinity is further corroborated by the fact that in almost all East Vardar provinces the basic rocks are accompanied with ubiquitously present and in some prov- inces very abundant felsic rocks. These felsic rocks (excluding oceanic plagiogranites), as it can be expected, display even more pronounced geochemical signature of subduction. However, the message taken from their characteristics is by no means clear, because certain issues regarding their origin and evolution still wait to be adequately constrained.

It is clear that the felsic rocks related to the East Vardar ophiolites are heterogeneous both compositionally and in terms of relative age of emplacement. For instance, most of the felsic rocks comprised by this study represent true intraophiolitic intrusives that appear as relatively small bodies always spatially enclosed by other ophiolites rock members. These, commonly collectively named intra-ophiolitic granitoids were regarded by many authors as representing felsic melts that originated during the evolution of this oceanic domain, which further means that these bodies have already been part of the ophiolite slices upon the ophiolite emplacement [31,33]. By contrast, larger masses of granitoids occurring mainly in southern Macedonia clearly cut the basement of the Serbo-Macedonian Massif [33]. Most of these granitoids contain crustal xenoliths and exhibit distinctive crustal-like in- 
compatible trace element patterns and $\mathrm{Sr}-\mathrm{Nd}$ isotopic signature. The granitoid of Fanos departs from this. It intrudes into the southern part of the Guevgeli complex and is interpreted as also postdating the emplacement of ophiolites (e.g. [38]), but it has distinctively less crustal-like isotopic characteristics, which are similar to the majority of intra-ophiolitic granitoid bodies [33, 37].

A weak adakitic affinity of some East Vardar intra-ophiolitic felsic rocks was mentioned in [33] for the occurrences in Serbia, but the authors did not give any geodynamic connotation to this observation. This issue has been given full attention in [37], who reported the presence of rocks of adakitic-like geochemical affinity in the Demir Kapija ophiolites. Božović et al. [37] argued that the adakitic-like magmas formed simultaneously with normal arc melts, and they used that as evidence for proposing a scenario of slab plus sediment melting in an unusually hot subduction zone (i.e. subduction of young oceanic crust). The authors went a step further and stated that this magmatism was associated with a progressive change in melting depth, suggesting that there was a relatively abrupt increase in temperature within the subducted slab soon after subduction initiation. They eventually concluded that the Demir Kapija ophiolites formed in a short-lived (intra-oceanic) back-arc basin. However, Zachariadis [38] and Saccani et al. [39] did not recognize a significant adakitic geochemical signature in the rocks occurring in the Greek part of the Guevgeli complex.

In order to contribute to this issue, here we plot all the felsic rocks comprised by this synthesis on the classical Y vs Sr/Y diagram for distinguishing between the normal arc and adakitic magmas [75]. We limited the vertical axis to only slightly elevated $\mathrm{Sr} / \mathrm{Y}$ values $(<60)$ in order to see the samples distribution better. It can be seen that the felsic rocks from most of the East Vardar provinces indeed show weak adakitic characteristics, with maybe the exception of the Circum Rhodope ophiolites, which can be due to sample bias. Note, for instance, that some samples from the South Apuseni and the Serbian East Vardar ophiolites exhibit distinctively higher $\mathrm{Sr} / \mathrm{Y}$ values than do most rocks from Demir Kapija. In addition, the group of the granites that presumably intrude both the East Vardar ophiolites and the basement is dividied into two subgroups. The Fanos rocks (red dots circled by a red line) plot towards the elevated $\mathrm{Sr} / \mathrm{Y}$ values, whereas the granitoids from southern Macedonia (the rest of the red dots) have typical normal arc (i.e. crustal-like) geochemical characteristics.

\section{Summary of geological and geochemical information: What does it say about geodynamics?}

Numerous authors offered their geodynamic interpretations of the East Vardar ophiolites usually including appropriate geotectonic sketches and drawings (e.g. [31, 37-39], among others). The majority of these geotectonic interpretations are based on at least three common points: 1) the East Vardar ophiolites originated in a relatively narrow oceanic basin, 2) the basin was short-lived, namely, it formed, evolved and closed in a relatively short time-span between early/middle to uppermost $\mathrm{Ju}$ rassic, 3) this oceanic realm originated in a backarc position of the eastward (present coordinates) subducting oceanic plate of the much wider Neotethys/West Vardar or Meliata ocean. However, there are also significant differences in the suggested geodynamic views. Ionescu et al. [30] proposed westward subduction for the origin of South Apuseni and Transylvania ophiolites in order to explain the clear evidence that these ophiolites slices were obducted onto the European plate. For the southern East Vardar provinces, disagreements are related to the immediate setting in which spreading of the narrow oceanic realm occurred. Zachariadis [38] and Božović et al. [37] regard the East Vardar ocean as having developed within the already existing ocean floor of Neotethys, i.e. in an intraoceanic environment. Consequently, they understand the Paikon block as an immature island arc behind which back-arc spreading of East Vardar has occurred. Other authors (e.g. [39, 40, 72, 76],) argued that the Paikon block was founded by the Paleozoic basement and that it was a continental ribbon splitoff the westernmost European margin. In such a scenario, the East Vardar oceanic segment formed in response to ensialic backarc rifting.

As the result of this synthesis, we propose a paleotectonic reconstruction graphically presented in Figure 8. It consists of four stages and comprises the period from early- to uppermost Jurassic. The orientation of major structures (mostly E-W) is different from those of the present day $(\mathrm{N}-\mathrm{S})$, which are the result of later rotations. The first stage (Figure 8A; early/mid-Jurassic) involves northnortheastward subduction of the West Vardar oceanic plate, which is the main cause for the formation of the East Vardar ocean. The subduction front is intra-oceanic in the east, whereas in the west it is much closer to the European continent. Note that there is another subduction within the Neotethys, it has the same orientation, but is situated more to the south. During the second stage (Fig- 
ure 8B; mid-Jurassic) a complex volcanic arc is formed along the ocean-continental transition corridor of the European margin. In the north, it represents an intra-oceanic immature arc, whereas in the south it develops on the continental lithosphere (the future Paikon block). Immediately following is the phase of back-arc spreading and the formation of the narrow oceanic stripe of East Vardar. The third stage (Figure 8C; mid-/Upper Jurassic) is characterized by the termination of the northward subduction of the West Vardar oceanic lithosphere and by the initiation of another subduction, this time along the very East Vardar ridge. This is the onset of the closure of the East Vardar Ocean, which will be completed when the previously mentioned volcanic arcs are docked to the European margin. The situation

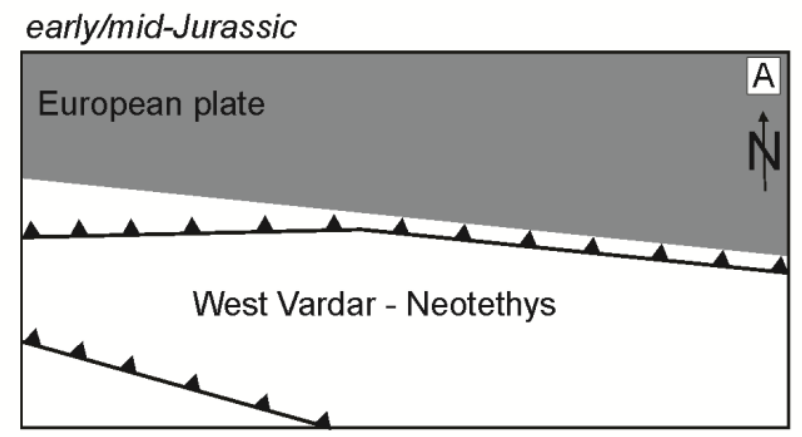

\section{mid-/Upper Jurassic}

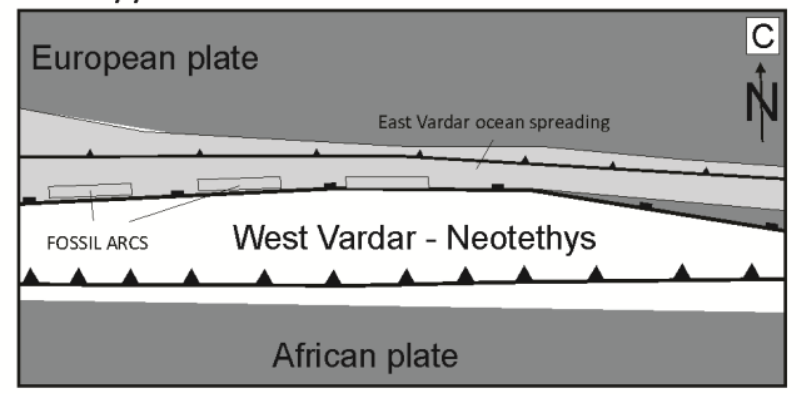

immediately following the closure of the East Vardar ocean is shown in the last sketch (Figure 8D; uppermost Jurassic). It shows that the uppermost Jurassic remnants of both West and East Vardar ocean floor have been emplaced as ophiolites. However, in contrast to the West Vardar ophiolites that have been rather homogeneously obducted onto the African margin, the emplacement of the East Vardar ophiolites was much more heterogeneous. In the north (South Apuseni and Transylvania), they have been obducted northwards onto the European plate, in the far south (Macedonia and Greece) they emplaced towards the south onto the Paikon block, whereas in the central part (Serbia) they likely accreted as steeply dipping ophiolites slices.

mid-Jurassic

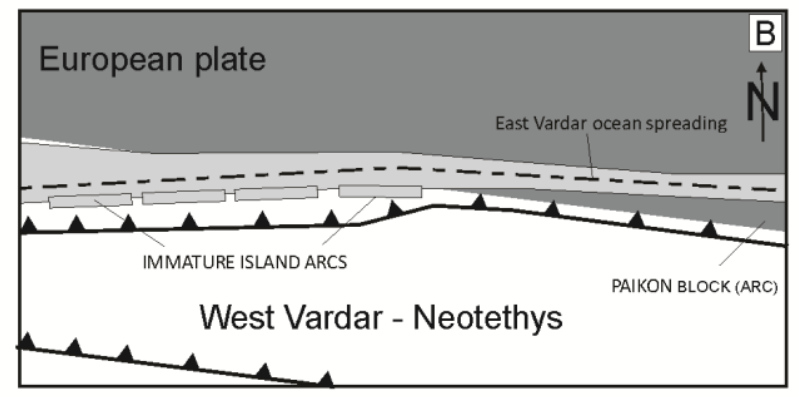

uppermost Jurassic

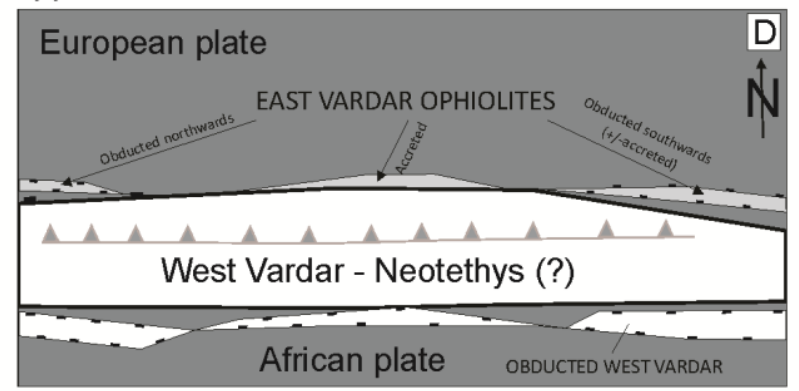

Figure 8. A sketch illustrating the paleotectonic reconstruction of the origin and evolution of East Vardar; the orientation of major structures is roughly $\mathrm{E}-\mathrm{W}$, i.e. different from their present day directions because of Cenozoic rotations; A) the first stage (early/mid Jurassic) involves north-northeastward subduction of the West Vardar oceanic plate; it is intraoceanic in character in the north and subduction under continent in the south; note that there is another intraoceanic subduction towards the south-southwest. B) The formation of a volcanic arc (mid Jurassic); it is an intraoceanic immature arc in the east, whereas in the west it forms onto the continental lithosphere (Paikon block); a narrow oceanic stripe of East Vardar's ocean floor is also formed. C) The termination of subduction of the West Vardar oceanic lithosphere and the initiation of subduction along the East Vardar ridge (mid/Upper Jurassic). D) The closure of the East Vardar ocean (uppermost Jurassic) and emplacement of both West and East Vardar ophiolites; note that the West Vardar ophiolites are found homogeneously obducted onto the African margin, whereas the East Vardar ophiolites are obducted northwards (onto European plate) in the east (in the north in present coordinates), southwards (onto the Paikon block) in the west (in the south in present coordinates) and simply accreted as steeply dipping ophiolites slices in the central parts.

In summary, the available data allow for having relatively clear ideas about the origin and evolution of the East Vardar ophiolites and in particular to recognize striking differences between these ophiolites and the much more widespread ophiolites of the West Vardar. However, in order to make a new step forward in our knowledge of the evolution of the East Vardar Ocean as well as in order to 
be able to refine the existing geodynamic models significantly, we need more information with regards to almost all aspects of these ophiolite rocks. We emphasize the three, albeit not exhaustive questions: i) what is the true structural position of the East Vardar ophiolites slices in Serbia, ii) were the East Vardar ophiolites in Serbia formed via intraoceanic subduction, and iii) what is the real significance of the adakitic signature shown by rocks in East Vardar provinces other than Demir Kapija.

\section{CONCLUSIONS}

The synthesis of the available geological and geochemical data for the East Vardar ophiolites occurring in Romania, Serbia, Macedonia and Greece enable us to derive the following conclusions:

1) The East Vardar ophiolites display the most pronounced supra-subduction signature of all the Balkan ophiolite belts. These geochemical characteristics are evident in all the East Vardar provinces comprised by this study and are shown by both basic and accompanied acid- to intermediate rocks.

2) The structural position of the East Vardar ophiolitic slices is different. The northern occurrences in Romania clearly overlie the SuprageticSerbo-Macedonian unit, suggesting that they have emplaced onto the European plate. Towards the south, the contacts between the East Vardar ophiolites and adjacent units become steeper, whereas in the southernmost occurrences (Macedonia and Greece) they are west-vergent and lay upon the Paikon block.

3) The East Vardar was a narrow and shortlived oceanic realm that most likely closed via subduction initiated along the ridge axis. The adakiticlike geochemical signature is taken as evidence that this subduction involved slab (plus sediments) melting. A four-stage paleotectonic reconstruction is proposed.

4) In order to improve the existing geodynamic models there is a great need for more information about the true structural position of the East Vardar ophiolites slices in Serbia, about the possible continuation of the Paikon block towards the north and about the true significance of the adakitic signature that is shown by felsic rocks in many, if not all, East Vardar provinces.

Acknowledgements: This study is carried out in the frame of bilateral collaboration between the Macedonian Academy of Sciences and Arts and the Serbian Academy of Sciences and Arts. The authors thank to BSc student Jovan Resimić for help in preparing the excel data base as well as to an anonymous reviewer for useful corrections of the originally submitted manuscript.

\section{REFERENCES}

[1] G. M. Stampfli, G. Borel, The TRANSMED transects in space and time: constraints on the paleotectonic evolution of the Mediterranean domain, in: The TRANSMED Atlas: the Mediterranean Region from Crust to Mantle, W. Cavazza, F. M. Roure, W. Spakman et al. (eds.), Springer, Heidelberg, 2004, pp. 53-80.

[2] D. J. J. van Hinsbergen, E. Hafkenscheid, W. Spakman, J. E. Meulenkamp, W. Wortel, Nappe stacking from subduction of oceanic and continental lithosphere below Greece, Geology, 33 (2004), pp. 325-328.

[3] C. Faccenna C. L. Jolivet, C. Piromallo et al., Subduction and the depth of convection in the Mediterranean mantle, J. Geophys. Res., 108 (2003), p. 2099.

[4] S. M. Schmid, E. Kissling, The arc of the Western Alps in the light of geophysical data on deep crustal structure, Tectonics, 19 (2000), pp. 62-85.

[5] M. S. Schmid, D. Bernoulli, B. Fügenschuh, L. Matenco, S. Schefer, R. Schuster, M. Tischler, K. Ustaszewski, The Alps-Carpathians-Dinarides connection: a correlation of tectonic units, Swiss J. Geosci., 101 (2008), pp. 139-183.

[6] M. Săndulescu, Cenozoic tectonic history of the Carpathians, in: The Pannonian Basin. A Study in Basin Evolution, L. H. Royden, F. Horvath (eds), AAPG Mem 35, 1988, pp. 17-25.

[7] J. Haas, S. Pero, Mesozoic evolution of the Tisza Mega-unit, Int. J. Earth Sci., 93 (2004), pp. 297313.

[8] J-P. Rampnoux, Regards sur les Dinarides internes yougoslaves (Serbie-Monténégro oriental): stratigraphie, évolution paléogéographique, magmatisme, Bull. Soc. géolog. France, 12, 6 (1970), pp. 948-966.

[9] A. G. Smith, J. G. Spray, A half-ridge transform model for the Hellenic-Dinaric ophiolites, in: The Geological Evolution of the Eastern Mediterranean, J. E. Dixon et al. (eds.), Geol. Soc. London Spec. Publ., 17, (1984), pp. 589-603.

[10] V. Bortolotti, M. Marroni, I. Nicolae, L. Pandolfi, G. Principi, E. Saccani, An update of the Jurassic ophiolites and associated calc-alkaline rocks in the south Apuseni Mountains (western Romania), Ofioliti, 29, 1 (2004), pp. 5-18.

[11] V. Bortolotti, G. Principi, Tethyan ophiolites and Pangea break-up, Island Arc, 14 (2005), pp. 442470.

[12] J. E. T. Channell, H. W. Kozur, How many oceans? Meliata, Vardar, and Pindos oceans in 
Mesozoic Alpine paleogeography, Geology, 25 (1997), pp. 183-186.

[13] D. Mountrakis, Structural evolution of the Pelagonian Zone in northwestern Macedonia, in: Geological Evolution of the Eastern Mediterranean, J. E. Dixon, A. H. F. Robertson (eds.), Geol. Soc. London Spec. Publ., 17, (1984), pp. 581-590.

[14] A. H. F. Robertson, P. D. Clift, P. J. Degnan, G. Jones, Palaeogeographic and palaeotectonic evolution of the Eastern Mediterranean Neotethys, Palaeogeography, Palaeoclimatology, Palaeoecology, 87 (1991), pp. 289-343.

[15] J. Dercourt, M. Gaetani, B. Vrielynck, E. Barrier, B. Biju-Duval, M. F. Brunet, J. P. Cadet, S. Crasquin, M. Sandulescu, (eds.), Peri-Tethys Palaeogeographical Maps Atlas. CCMGCGMW, Paris, (2000).

[16] G. Stampfli, J. Moser, P. Favre, A. Pillevuit, J. C. Vannay, Permo-Mesozoic evolution of the western Tethys region: the Neotethys-East Mediterranean basin connection, in: Peri-Tethys Memoir 6, P. Ziegler, W. Cavazza, A. H. F. Robertson, S. Crasquin-Solea (eds.), Mem. Natn. Hist., Paris, Natural History Museum, Paris, 186, (2001), pp. 51-108.

[17] A. H. F. Robertson, S. Karamata, The role of subduction-accretion processes in the tectonic evolution of the Mesozoic Tethys in Serbia, Tectonophysics, 234 (1994), pp. 73-94.

[18] S. Karamata, The geological framework of the Balkan Peninsula: its origin due to the approach, collision and compression of Gondwanian and Eurasian units, in: Tectonic Development of the Eastern Mediterranean Region, A.H.F. Robertson, D. Mountrakis (eds), Geol. Soc. Lond. Spec. Publ., 260 (2006) pp. 155-178.

[19] A. H. F. Robertson, S. Karamata, K. Šarić, Overview of ophiolites and related units in the Late Palaeozoic-Early Cenozoic magmatic and tectonic development of Tethys in the northern part of the Balkan region, Lithos, 108 (2009), pp. 1-36.

[20] V. Cvetković, D. Prelević, S. Schmid, Geology of South-Eastern Europe, in: Mineral and Thermal Waters of Southeastern Europe, P. Papić (ed.), 2015, pp. 1-29.

[21] F. Kockel, H. Mollat, H. W. Walther, Geologie des Serbo-Mazedonischen Massivs und seines mesozoischen Rahmens (Nordgriechenland), Geol. Jahrb., 89 (1971), pp. 529-551.

[22] F. Kockel, H. Mollat, H. W. Walther, Erlauterungen zur geologischen karte der Chalkidiki und angrenzender Gebiete 1 : 100000 (Nord Griechenland), Bundesanstalt fur Geowissenschaften und Rohstoffe, Hannover, (1977),.

[23] A. Michard, B. Goffé, A. Liathi et al., Découverte du facies schiste bleu dans les nappes du CircumRhodope; un element d'une ceinture HP-BT éo- héllenique en Grèce septentrionale, Compte Rendu Académie des Sciences, 318, 2 (1994), pp. 15351542.

[24] B. C. Burchfiel, Geology of Romania, Geol. Soc. Am. Spec. Papers, 158, (1976), 82 pp.

[25] M. Bleahu, S. Bordea, M. Lupu, A. Ştefan, D. Patrulius, S. Panin, The structure of the Apuseni Mts. B3 Field trip guide, XII Congress of the Carpathian-Balkan Geological Association, Bucharest 1981. Institutul de Geologie şi Geofizică, 1981, $107 \mathrm{pp}$.

[26] I. Nicolae, Tectonic setting of the ophiolites from the South Apuseni Mountains: magmatic arc and marginal basin, Roman. J. Tect. Reg. Geol., 76 (1995), pp. 27-39.

[27] V. Bortolotti, M. Marroni, I. Nicolae, L. Pandolfi, G. Principi, E. Saccani. Geodynamic implications of Jurassic ophiolites associated with island-arc volcanics, South Apuseni Mountains, Western Romania, Int. Geol. Rev., 44 (2002), pp. 938-955.

[28] M. D. Dimitrijević, Geological Atlas of Serbia 1, 1:2.000.000, Republical Foundation for Geological Investigations and Geological Institute GEMINI, Grafimex, Belgrade, 1992.

[29] I. Nicolae, E. Saccani, Petrology and geochemistry of the Late Jurassic calcalkaline series associated to Middle Jurassic ophiolites in the South Apuseni Mountains (Romania), Schweizerische Mineralogische Petrographische Mitteilungen, 83 (2003), pp. 81-96.

[30] C. Ionescu, V. Hoeck, C. Tomek, F. Koller, I. Balintoni, L. Beşuţiu, New insights into the basement of the Transylvanian Depression (Romania), Lithos, 108 (2009), pp. 172-191.

[31] D. Gallhofer, A. von Quadt, S. M. Schmid, M. Guillong, I. Peytcheva, I. Seghedi, Magmatic and tectonic history of Jurassic ophiolites and associated granitoids from the South Apuseni Mountains (Romania), Swiss J. Geosci., 10, 2 (2017), pp. 699-719.

[32] K. Resimić, Petrology of igneous rocks of diabasechert formation near Kragujevac, Master Thesis, Faculty of Mining and Geology, University of Belgrade, (2000) 169 pp.

[33] K. Šarić, V. Cvetković, R. L. Romer, G. Christofides, A. Koroneos, Granitoids associated with East Vardar ophiolites (Serbia, F.Y.R. of Macedonia and northern Greece): Origin, evolution and geodynamic significance inferred from major and trace element data and $\mathrm{Sr}-\mathrm{Nd}-\mathrm{Pb}$ isotopes, Lithos, 108 (2009), pp. 131-150.

[34] M. Božović, Petrology and Geochemistry of the Balkan Ophiolites, Johannes Gutenberg University Mainz, PhD thesis, 2013, 254 pp.

[35] D. Petrović, V. Cvetkov, I. Vasiljević, V. Cvetković, A new geophysical model of the Serbian part of the East Vardar ophiolite: Implications 
for its geodynamic evolution, J. Geodyn., 90 (2015), pp.1-13.

[36] D. Petrović, V. Cvetkov, V. Cvetković, Spatial distribution of the Demir Kapija (Macedonia) ophiolite based on geomagnetic data, Tehnika, 2 (2016), pp. 215-220.

[37] M. Božović, D. Prelević, R. L. Romer, M. Barth, P. Den Bogaard, B. Boev, The Demir Kapija ophiolite, Macedonia (FYROM): a snapshot of subduction initiation within a back-arc, J. Petrol., 54, 7 (2013), pp. 1427-1453.

[38] P. Zachariadis, Ophiolites of the Eastern Vardar Zone, N. Greece, $\mathrm{PhD}$ dissertation, Johannes $\mathrm{Gu}-$ tenberg-Universität, Mainz, 2007, pp. 1-131.

[39] E. Saccani, V. Bortolotti, M. Marroni, L. Pandolfi, A. Photiadis, G. Principi, The Jurassic association of backarc basin ophiolites and calc-alkaline volcanics in the Guevgueli complex (Northern Greece): implications for the evolution of the Vardar zone, Ofioliti, 33 (2008), pp. 209-227.

[40] N. Bonev, P. Marchev, R. Moritz et al., Jurassic subduction zone tectonics of the Rhodope Massif in the Thrace region (NE Greece) as revealed by new U-Pb and ${ }^{40} \mathrm{Ar} /{ }^{39} \mathrm{Ar}$ geochronology of the Evros ophiolite and high-grade basement rocks, Gondwana Res., 27 (2015), pp. 760-775.

[41] K. Resimić-Šarić, S. Karamata, A. Popević, K. Balogh, The eastern branch of the Vardar zone the scar of the main Vardar ocean, in: Geology and Metallogeny of the Dinarides and the Vardar zone, S. Karamata, S. Janković (eds.), Zvornik, 2000, pp. 81-85.

[42] K. Resimić-Šarić, V. Cvetković, K. Balogh, Radiometric K/Ar data as evidence of the geodynamic evolution of the Zdraljica Ophiolitic Complex (central Serbia). Ann. Géol. Pénin. Balk., 66, (2005), pp. 73-79.

[43] M. Malešević, M. Vukanović, T. Brković, J. Obradović, L. Karajičić, M. D. Dimitrtijević, R. Stanislavijević, Basic Geologcal Map SFRY, 1:100.000, Sheet Kuršumlija and Explanations, 1978.

[44] M. N. Dimitrijević, M. D. Dimitrijevic, The Turbiditic Basins of Serbia, Serbian Academy of Sciences and Arts, Department of Natural and Mathematical Sciences, 1987.

[45] M. D. Dimitrijević, Geology of Yugoslavia, Geological Institute GEMINI spec. publ., Belgrade, (1997).

[46] M. D. Dimitrijević, Dinarides and the Vardar Zone: a short review of the geology, Acta Vulcan., 13 (2001), pp. 1-8.

[47] J. Mercier, Mouvements orogéniques et magmatisme d'age Jurassique Supérieur-É ocrétacé dans les Zones Internes des Hellénides (Macédoine, Grèce), Revue de Géographie Physique et de Géologie Dynamique, 2, VIII (4) (1966), pp. 265-278.
[48] S. A. M. Brown, A. H. F. Robertson, Sedimentary geology as a key to understanding the tectonic evolution of the Mesozoic-Early Tertiary Paikon Massif, Vardar suture zone, N Greece, Sedim. Geol., 160 (2003), pp. 179-212.

[49] B. Anders, T. Reischmann, U. Poller, D. Kostopoulos, Age and origin of granitic rocks of the eastern Vardar Zone, Greece: new constraints on the evolution of the Internal Hellenides, $J$. Geol. Soc., 162 (2005), pp. 857-870.

[50] B. Boev, S. Lepitkova, The age of the ophiolite rocks on the territory of the Republic of Macedonia. XVII Congress of the Carpathian-Balkan Geological association, 2002, Bratislava.

[51] B. Boev, D. Prelević, M. Božović, S. Erić, V. Cvetković, Olivine websterite veins cutting the rabrovo serpentinites (south Macedonia): new evidence of the arc setting of the East Vardar Ophiolites?, Contributions, MASA, Sec. Nat. Math. Biotech. Sci., 34 (1-2), (2013), pp. 69-81.

[52] K. Šarić, V. Cvetković, R. L. Romer, I. Peytcheva, A. von Quadt, Petrogenesis of intraophiolitic calcalkaline and tholeiitic granitoids of Eastern realm of the Vardar zone in Serbia, in: Proceedings of the 15th Congress of Geologists of Serbia with International Participation, N. Banjac (ed.), Belgrade, (2010), p. 43.

[53] D. Kukoč, Š. Goričan, A. Košir et al., Middle Jurassic age of basalts and the post-obduction sedimentary sequence in the Guevgueli Ophiolite Complex (Republic of Macedonia), Int. J. Earth Sci., 104 (2), (2015), pp. 435-447.

[54] J. Bébien, L'association igne'e de Gue'vgue'li (Mace'doine grecque), Expressiond'un magmatisme ophiolitique dans une de'chirure continentale. DSc thesis, Universite' de Nancy I. (1982).

[55] J. G. Spray, J. Babien, D. C. Rex, J. C. Roddick, Age constraints on the igneous and metamorphic evolution of the Hellenic-Dinaric ophiolites, Geol. Soc. London, Sp. Publ., 17 (1984) pp. 619-627.

[56] T. Danelian, A. H. F. Robertson, S. Dimitriadis, Age and significance of radiolarian sediments within basic extrusives of the marginal basin Guevgueli Ophiolite (northern Greece), Geol. Mag., 133 (1996), pp. 127-136.

[57] E. Sapountzis, The Thessaloniki gabbros, Petrology, 20 (1979), pp. 37-70.

[58] S. Dimitriadis, Discussion of 'The Thessaloniki Gabbros' by E. Sapountzis, J. Petrol., 21 (1980), pp. 437-440.

[59] J. Mercier, P. Vergély, J. Bébien, Les ophiolites helléniques »obductées« au Jurassique supérieur sont-elles les vestiges d'un Océan téthysien ou d'une mer marginale péri-européene? Comptes Rendes Sommaires de la Soc. Géol. France, 17 (1975), pp. 108-111. 
[60] K. Mussallam, D. Jung, Petrology and geotectonic significance of salic rocks preceding ophiolites in the eastern Vardar Zone, Greece. TMPM Tschermaks Mineralogische und Petrographische Mitteilungen, 35 (1986) pp. 217-42.

[61] A. H. F. Robertson, Overview of the genesis and emplacement of Mesozoic ophiolites in the Eastern Mediterranean Tethyan region, Lithos, 65 (2002), pp. 1-67.

[62] G. Christofides, T. Soldatos, A. Koroneos, Geochemistry and evolution of the Fanos granite, N. Greece, Miner. Petrol., 43 (1990), pp. 49-63.

[63] G. Christofides, A. Koroneos, T. Soldatos, G. Eleftheriadis, A. Kilias, Eocene magmatism (Sithonia and Elatia plutons) in the Internal Hellenides and implications for Eocene-Miocene geological evolution of the Rhodope massif (Northern Greece), in: Tertiary Magmatism in the Dinarides, Acta Vulcanologica, H. Downes, V. Orlando (eds.), 13 (2001), pp. 73-89.

[64] G. Kauffmann, F. Kockel, H. Mollat, Notes on the stratigraphic and paleogeographic position of the Svoula formation in the Innermost Zone of the Hellenides (Northern Greece), Bull. Soc. Géol. France, 18 (1976), pp. 225-230

[65] J. A. Winchester, P. A. Floyd, Geochemical Discrimination of Different Magma Series and Their Differentiation Products Using Immobile Elements, Chem. Geol., 20 (1977), pp. 325-343.

[66] M. J. Le Bas, R. W. Le Maitre, A. Streckeisen, B. A. Zanettin, Chemical classification of volcanic rocks based on the total alkali silica diagram. $J$. Petrol., 27 (1986), pp. 745-750.

[67] B. Lugović, R. Altherr, I. Raczek, A. W. Hofmann, V. Majer, Geochemistry of peridotites and mafic igneous rocks from the Central Dinaric Ophiolite Belt, Yugoslavia, Contrib. Miner. Petrol., 106 (1991), pp. 201-216.

[68] J. Pamić, B. Tomljenović, D. Balen, Geodynamic and petrogenetic evolution of Alpine ophiolites from the central and NW Dinarides: an overview, Lithos, 65 (2002), pp. 113-142.

[69] W. F. McDonough, S.-s. Sun, The composition of the Earth, Chem. Geol., 120 (1995), pp. 223-253.

[70] S. Patrascu, M. Bleahu, C. Panaiotu, Tectonic implications of paleomagnetic research into Upeer Cretaceous magmatic rocks in the Apuseni Mountains, Romania, Tectonophysics, 180 (1990), pp. 309-322.

[71] E. Márton, M. Tischler, L. Csontos, B. Fügenschuh, S. Schmid, S., The contact zone between the ALCAPA and Tisza-Dacia megatectonic units of Northern Romania in the light of new paleomagnetic data, Swiss J. Geosci., 100 (2007), pp. 109-124.

[72] S. A. M. Brown, A. H. F. Robertson, Evidence for Neotethys rooted within the Vardar suture zone from the Voras Massif, northernmost Greece, Tectonophysics, 381 (2004), pp. 143-173.

[73] J. A. Pearce, Trace element characteristics of lavas from destructive plate boundaries, in: Andesites: Orogenic Andesites and Related Rocks, R. S. Thorpe (ed.), John Wiley \& Sons, Chichester, U.K., 1982, pp. 525-548.

[74] L. C. Patino, M. J. Carr, M. D. Feigenson, Local and regional variations in Central American arc lavas controlled by variations in subducted sediment input, Contrib. Miner. Petrol., 138 (2000), pp. $265-283$.

[75] M. J. Defant, M. S. Drummond, Derivation of some modern arc magmas by melting of young subducted lithosphere, Nature, 347 (1990), pp. $662-665$.

[76] J. Ferrière, A. Stais, Nouvelle interprétation de la suture téthysienne vardarienne d'après l'analyse des séries de Péonias (Vardar oriental, Hellénides internes), Bull. Soc. Géol. France, 166 (1995) pp. 327-339.

\title{
НОВ ПОГЛЕД НА ОФИОЛИТИТЕ ОД ИСТОЧНАТА ВАРДАРСКА ЗОНА: КРАТКА СИНТЕЗА НА ГЕОЛОГИЈАТА И ГЕОХЕМИСКИТЕ ПОДАТОЦИ
}

\author{
Блажо Боев ${ }^{*}$, Vladica Cvetković², Dejan Prelević², Kristina Šarić², Иван Боев ${ }^{1}$ \\ ${ }^{1}$ Универзитет „Гоце Делчев“, Штип, Република Македонија \\ ${ }^{2}$ Faculty of Mining and Geology, University of Belgrade, Belgrade, Serbia
}

Во оваа студија се објавуваат и синтетизираат геолошките и геохемиските податоци за источно вардарските офиолити, вклучувајќ ги и најпознатите појави од Јужните Апусенски Планини во Романија до врвот на полуостровот Халкидики во Грција. Овие збирни геолошки податоци укажуваат на тоа дека источновардарските офиолити во најголем дел се изградени од магматски секвенци, со многу мала застапеност на карпите во обвивката. Членовите на магматската секвенца се карактеризираат со присуство на поголема количина кисели и интермедијарни вулкански и интрузивни карпи. Староста на овие офиолити е одредена палеонтолошки и радиометриски и податоците укажуваат на тоа дека источновардарските офиолити се 
формирале како краткотрајно океанско подрачје кое било активно пред горен кимериски период. Присутен е релативно слаб адакитски афинитет во интраофиолитските кисели и интермедијарни карпи во многу предели од Источновардарскиот регион.

Ова може да се земе како доказ дека на младата и жешка плоча се појавила субдукција, најверојатно со претходно ширење на гребенот. Се предлага палео-тектонската реконструкција од четири фази. Таа вклучува: а) рана/средна јурска северо-североисточна субдукција на западновардарската океанска плоча; б) формирање на среднојурски вулкански лак и тесен задлачен басен на океанскиот појас на Источновардарската зона; в) средно-/горнојурско започнување на субдукција на Источновардарската зона над оската на гребенот, г) комплексно и хетерогено поставување на офиолитите на Источновардарската зона. Податоците кои се достапни даваат релативно јасна слика за потеклото и еволуцијата на офиолитите на Источновардарската зона. Сепак, за да се овозможи подобро разбирање на сите аспекти на еволуцијата, треба да одговориме на дополнителни прашања кои се однесуваат на вистинската структурна поврзаност на делови на офиолитите на Источновардарската зона во Србија, вистинската природа на субдукцијата која е причинител на задлачното ширење на кората (интраокеанско наспроти субдукција под континентот?) и целосното значење на адакитските својства на карпите во пределите на источен вардарски регион надвор од Демир Капија.

Клучни зборови: офиолити; субдукција; задлачен басен; Тетис; Балкански Полуостров 